\title{
'El Dorado' and 'La Estrella': Compact Plant Tropical Pumpkin Hybrids
}

\author{
Donald N. Maynard \\ Gulf Coast Research and Education Center, University of Florida, Bradenton, \\ FL 34203
}

Gary W. EImstrom

Sunseeds, 7087 E. Peltier Road, Acampo, CA 95220

\section{Stephen T. Talcott}

Food Science and Human Nutrition Department, University of Florida, Gainesville, FL 32611

\author{
R. Bruce Carle \\ Hollar Seeds, P.O. Box 106, Rocky Ford, CO 81067
}

Additional index words. Cucurbita moschata, vegetable breeding, calabaza, squash

Cucurbita moschata Duchesne, known as calabaza in Puerto Rico and in Florida by those of Latino descent, is a species of pumpkin that is grown throughout the tropics and subtropics. It is known as pumpkin or calabash in the English-speaking Caribbean islands, auyama in the Dominican Republic, ayote in Central America, and zapallo in South America. Plants are monoecious, and insects, mostly honeybees and bumblebees, are required for pollen transfer. Fruit are produced along trailing vines that may spread up to $15 \mathrm{~m}$ from the crown of the plant. Each plant commonly produces two to five fruit that range from 2 to $20 \mathrm{~kg}$ each. The variability in fruit weight causes packaging problems because pumpkins are often marketed in 23-kg burlap sacks resulting in as few as two or as many as 10 pumpkins per sack. Fruit shape varies from globe, round, oval, obovate, pear, and oblate in unimproved types. Likewise, rind color varies from green immature fruit to light-orange mature fruit and in rind pattern from piebald to mottled. The rind may be smooth or sutured. The fruit flesh varies in color through several shades of yellow to orange and is from 3 to $5 \mathrm{~cm}$ thick.

Although widely grown in tropical America, pumpkin plantings are generally small and most do not exceed a few hectares in size. Tropical pumpkin is the most important nonroot vegetable in Puerto Rico, where per capita annual consumption is $\approx 7 \mathrm{~kg}$ compared to $<6 \mathrm{~kg}$ for tomato, the second most important vegetable (Alamo, 1990). In Jamaica, tropical pumpkin is the principal ingredient of pumpkin soup, a national culinary treasure.

Received for publication 22 Oct. 2001. Accepted for publication 9 Apr. 2002. This research was supported by the Florida Agricultural Experiment Station and a grant from the U.S. Dept. of Agriculture, Tropical/Subtropical Agriculture Research Programs and approved for publication as Journal Series No. R-08431
In Florida, fruit characteristics deemed to be important in high-quality tropical pumpkins by researchers, market personnel, and growers are: freedom from cracking; comparatively large, round fruit with a smooth, light-green rind; deep-yellow internal color; thick internal flesh; and high soluble solids (Volin et al., 1976). Importers of tropical pumpkins (personal communication) from the Caribbean and Central America believe that their requirements are best met with regularly shaped, flat or round fruit that weigh $\approx 4-5 \mathrm{~kg}$ each, and have smooth, tough, buff-colored rind. The fruit must have a closed blossom end and have a thick, dark-orange fruit flesh since many fruit are sold as cut fruit in the market.

r.
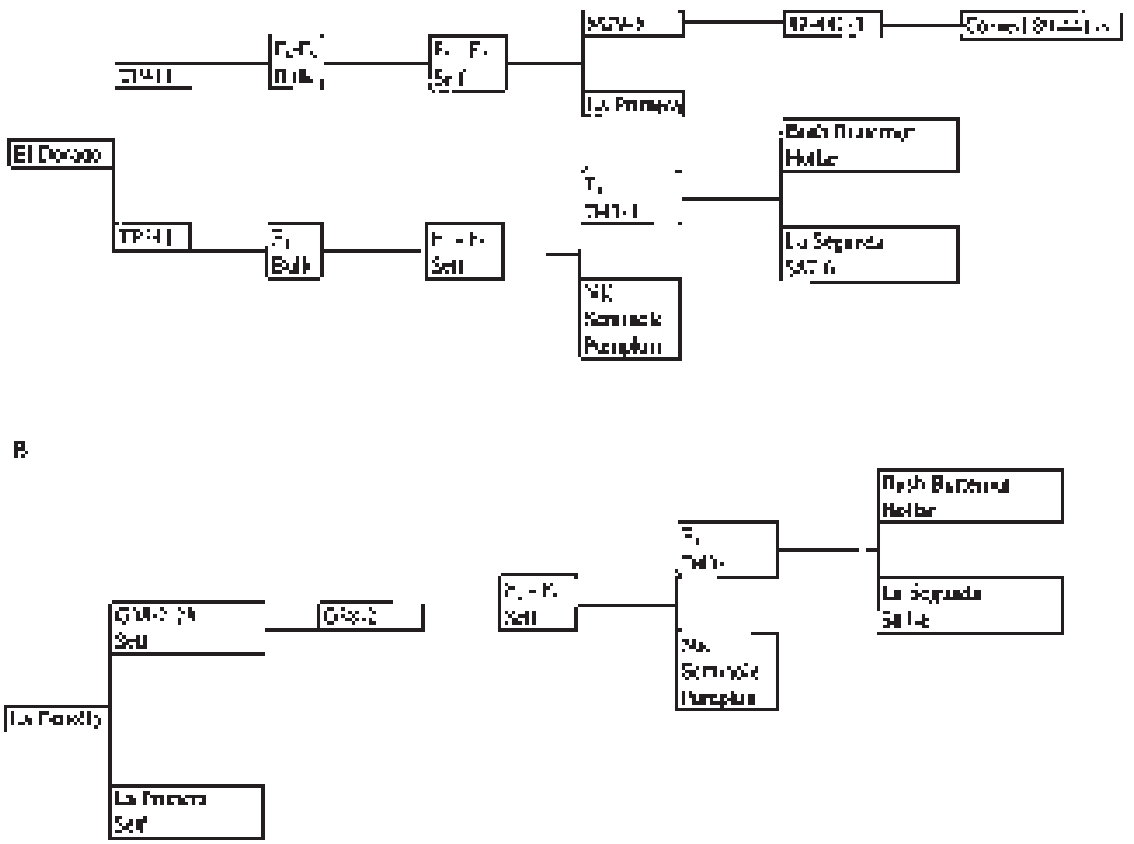

Fig. 1. Pedigree of (A) 'El Dorado' and (B) ‘La Estrella' tropical pumpkins. adaptation, and disease resistance.
Currently, open-pollinated cultivars developed in Florida or Puerto Rico or farmerselected landraces are used by growers. Farmersaved seeds are generally used because commercially produced seed is not readily available. As a result, genetic contamination is exacerbated in this already diverse crop. Growers use cultivars or derived selections from ' $\mathrm{La}$ Primera', introduced by the Florida Agricultural Experiment Station (Volin, 1979); 'La Segunda', developed by Volin but not formally introduced; and 'Soler', selected in Puerto Rico but not formally introduced. These cultivars are traditional long-vine types.

Our objectives were to develop hybrid tropical pumpkins with a compact plant habit, uniform fruit size, and desirable fruit quality. Hybrid seed provides a profit incentive based on exclusivity that encourages a commercially available seed supply. A compact plant habit permits higher plant populations, easier cultivation, and a more concentrated maturity, which facilitates production.

\section{Origin}

Ongoing breeding programs (1987present) at the Univ. of Florida have generated advanced compact tropical pumpkin lines and trueline reselections of landrace cultivars. The compact material was derived using pedigree and backcross breeding strategies. 'Bush Butternut' and 'Burpee Butterbush' were used as genetic sources for shortened internode, deeporange flesh, and high flesh dry matter. Heterogenous selections of 'Borinquen', 'Seminole', 'Linea C Pinta', 'La Primera', 'La Segunda', and 'Soler' were used as sources for tropical pumpkin fruit characteristics, tropical

The advanced lines were used to generate 260 different $F_{1}$ hybrids in 1996 and 1997. Two types of hybrids were constructed based 
Table 1. Marketable yield, average fruit weight, anthesis, fruit per plant, and fruit characteristics of tropical pumpkins. Mid-Florida Research and Education Center, Leesburg, Fla. Spring 1999.

\begin{tabular}{|c|c|c|c|c|c|c|c|c|}
\hline \multirow[b]{2}{*}{ Cultivar $^{2}$} & \multirow{2}{*}{$\begin{array}{c}\text { Marketable } \\
\text { yield } \\
\left(\mathrm{t} \cdot \mathrm{ha}^{-1}\right)\end{array}$} & \multirow{2}{*}{$\begin{array}{c}\text { Avg fruit } \\
\text { wt } \\
(\mathrm{kg})\end{array}$} & \multicolumn{2}{|c|}{ Anthesis (DAP)y } & \multirow{2}{*}{$\begin{array}{l}\text { Fruit } \\
\text { per } \\
\text { plant }\end{array}$} & \multirow{2}{*}{$\begin{array}{l}\text { Flesh } \\
\text { color } \\
(1-5)^{\mathrm{x}} \\
\end{array}$} & \multirow{2}{*}{$\begin{array}{l}\text { Fruit } \\
\text { shape }\end{array}$} & \multirow{2}{*}{$\begin{array}{c}\text { Dry } \\
\text { matter } \\
(\%) \\
\end{array}$} \\
\hline & & & Female & $\overline{\text { Male }}$ & & & & \\
\hline El Dorado & $43.0 \mathrm{~b}^{\mathrm{w}}$ & $2.5 \mathrm{c}$ & 47 & 50 & $2.4 \mathrm{a}$ & 3 & Round & $9.6 \mathrm{a}$ \\
\hline La Estrella & $52.1 \mathrm{a}$ & $3.9 \mathrm{~b}$ & 38 & 46 & $1.9 \mathrm{~b}$ & 2 & Oblate & $8.4 \mathrm{a}$ \\
\hline La Segunda & $13.8 \mathrm{c}$ & $4.8 \mathrm{a}$ & 58 & 66 & $1.8 \mathrm{~b}$ & 2 & Round & $4.4 \mathrm{~b}$ \\
\hline
\end{tabular}

"Plant populations per ha were 7160 for 'El Dorado' and 'La Estrella' and 1791 for 'La Segunda'.

y DAP = days after planting

${ }^{\mathrm{x}} 1=$ light yellow to $5=$ dark orange.

wMean separation in columns by Duncan's multiple range test, $5 \%$ level.

Table 2. Marketable yield, average fruit weight, anthesis, fruit per plant, fruit characteristics, and cull weight of tropical pumpkins. Gulf Coast Research and Education Center, Bradenton, Fla. Fall 1999, Spring 2000, Spring 2001.

\begin{tabular}{|c|c|c|c|c|c|c|c|c|c|c|}
\hline \multirow[b]{3}{*}{ Cultivar $^{2}$} & \multirow{3}{*}{$\begin{array}{c}\text { Marketable } \\
\text { yield } \\
\left(\mathrm{t} \cdot \mathrm{ha}^{-1}\right) \\
\end{array}$} & \multirow{3}{*}{$\begin{array}{c}\text { Avg fruit } \\
\text { wt } \\
(\mathrm{kg})\end{array}$} & \multirow{2}{*}{\multicolumn{2}{|c|}{ Anthesis (DAP) $)^{y}$}} & \multicolumn{6}{|c|}{ Fruit characteristics } \\
\hline & & & & & \multirow{2}{*}{$\begin{array}{c}\text { Fruit } \\
\text { per } \\
\text { plant }\end{array}$} & \multirow{2}{*}{$\begin{array}{c}\text { Flesh } \\
\text { thickness } \\
(\mathrm{cm})\end{array}$} & \multirow{2}{*}{$\begin{array}{l}\text { Flesh } \\
\text { color } \\
(1-5)^{\mathrm{x}} \\
\end{array}$} & \multirow{2}{*}{$\begin{array}{c}\text { Equatorial: } \\
\text { polar } \\
\text { ratio }^{w} \\
\end{array}$} & \multirow{2}{*}{$\begin{array}{c}\text { Dry } \\
\text { matter } \\
(\%)\end{array}$} & \multirow{2}{*}{$\begin{array}{c}\text { Cull } \\
\text { wt } \\
\left(\mathrm{t} \cdot \mathrm{ha}^{-1}\right) \\
\end{array}$} \\
\hline & & & Female & Male & & & & & & \\
\hline El Dorado & $27.7 \mathrm{a}^{\mathrm{v}}$ & $2.3 \mathrm{~b}$ & $40 \mathrm{a}$ & $42 \mathrm{a}$ & $3.0 \mathrm{a}$ & $3.6 \mathrm{a}$ & $4.7 \mathrm{a}$ & $0.9 \mathrm{~b}$ & --- & --- \\
\hline La Estrella & $30.3 \mathrm{a}$ & $3.5 \mathrm{a}$ & $33 \mathrm{~b}$ & $38 \mathrm{~b}$ & $2.2 \mathrm{a}$ & $4.0 \mathrm{a}$ & $3.8 \mathrm{~b}$ & $1.4 \mathrm{a}$ & --- & --- \\
\hline \multicolumn{11}{|c|}{ Spring 2000} \\
\hline La Primera & $42.6 \mathrm{~b}$ & $5.1 \mathrm{a}$ & $46 \mathrm{~b}$ & $54 \mathrm{a}$ & $4.6 \mathrm{a}$ & $4.6 \mathrm{a}$ & $4.9 \mathrm{a}$ & $1.29 \mathrm{a}$ & $14.0 \mathrm{a}$ & $0.7 \mathrm{~b}$ \\
\hline \multicolumn{11}{|c|}{ Spring 2001} \\
\hline El Dorado & $97.1 \mathrm{a}^{\mathrm{w}}$ & $3.2 \mathrm{~b}$ & $51 \mathrm{a}$ & $52 \mathrm{~b}$ & $4.3 \mathrm{a}$ & $4.6 \mathrm{a}$ & $4.1 \mathrm{a}$ & $1.1 \mathrm{c}$ & $10.0 \mathrm{a}$ & $7.2 \mathrm{a}$ \\
\hline La Estrella & $61.7 \mathrm{~b}$ & $3.0 \mathrm{~b}$ & $37 \mathrm{~b}$ & $49 c$ & $3.0 \mathrm{~b}$ & $4.0 \mathrm{a}$ & $2.8 \mathrm{~b}$ & $1.4 \mathrm{a}$ & $11.7 \mathrm{a}$ & $9.3 \mathrm{a}$ \\
\hline La Primera & $61.2 \mathrm{~b}$ & $6.3 \mathrm{a}$ & $51 \mathrm{a}$ & $57 \mathrm{a}$ & $2.2 \mathrm{c}$ & $5.1 \mathrm{a}$ & $4.4 \mathrm{a}$ & $1.2 \mathrm{~b}$ & $11.8 \mathrm{a}$ & $11.6 \mathrm{a}$ \\
\hline
\end{tabular}

'Plant populations per ha were 3984 in Fall 1999, 7172 for 'El Dorado' and 'La Estrella' and 1993 for 'La Primera' in Spring 2000, and 7172 in Spring 2001.

${ }^{\mathrm{D}} \mathrm{DAP}=$ days after planting.

${ }^{\mathrm{x}} 1=$ light yellow to $5=$ dark orange.

${ }^{\mathrm{w}}<1=$ oval, $1=$ round, $>1=$ flattened.

'Mean separation in columns within years by Duncan's multiple range test, $5 \%$ level.

on the parental plant habits: compact $\times$ compact plant and compact plant $\times$ long-vined types. Preliminary evaluations in 1997 and 1998 were conducted at two locations with different environments and production methods: Mid-Florida Research Center, Leesburg, Fla., and Gulf Coast Research and Education Center, Bradenton, Fla. Advanced evaluations were conducted at Leesburg in Spring 1999 and at Bradenton in Fall 1999, Spring 2000, and Spring 2001.

'El Dorado' originated from a cross between TP 411 and TP 241 (Fig. 1). TP 411 was developed from Cornell 89-441-3, a reduced vine butternut-type breeding line (Munger, 1990). 'La Primera' was included to obtain the tropical pumpkin fruit type and subsequent selections were made for round fruit and compact vines. TP 241 was developed from a cross between 'Bush Butternut' obtained from Hollar Seeds, Rocky Ford, Colo., and 'La Segunda'. 'Seminole' pumpkin was introduced for its deep-orange flesh. Selections were made for compact plant type and desirable fruit characteristics.

One parent of 'La Estrella' (Fig. 1) has a similar background as one parent of 'El Dorado' in that prior to the selection and selfing of G382-38 their parentage is the same. The other parent of 'La Estrella' is 'La Primera', which had been selfed for many generations.

\section{Description}

'El Dorado' and 'La Estrella' tropical pumpkins were evaluated at the Univ. of Florida Mid-Florida Research and Education CenterLeesburg (Table 1) and at the Gulf Coast Research and Education Center-Bradenton (Table 2). A traditional long-vine cultivar was included in most trials. In aggregate, the hybrids produced much higher yields, had more fruit per plant, and were earlier maturing than the traditional long-vine cultivars. However, the traditional type produced larger fruit with thicker flesh. There was no consistent difference in flesh color or dry matter content between the new hybrids and traditional cultivars.

'El Dorado' (Fig. 2) is round with green immature rind and buff-colored mature rind. The name was selected because of its bright orange flesh. 'La Estrella' (Fig. 2) is oblate with an immature green pinta pattern rind that becomes buff pinta at maturity. It was named for the starlike pattern radiating from the peduncle that is particularly noticeable on immature fruit.

'El Dorado' and 'La Estrella' are similar in many ways but differ in maturity, plant habit, and flesh color. 'La Estrella' is considerably earlier than 'El Dorado'; pistillate flower anthesis was 7-14 d earlier and staminate flower anthesis was 3-5 dearlier (Tables 1 and 2). 'El Dorado' plants are more compact than 'La Estrella' plants. Both hybrids produce bushtype plants that set one to three fruit at the crown. Thereafter, 'El Dorado' plants develop short runners and 'La Estrella' plants develop longer branches where an additional one to three fruit set. From limited spacing trials, it appears that both hybrids perform well when provided 1.4 to $2.2 \mathrm{~m}^{2} /$ plant. In contrast, traditional vining cultivars require at least $3.4 \mathrm{~m}^{2} /$ plant. Flesh color of 'El Dorado' was rated 4.3 compared to 3.2 for 'La Estrella'.

Tropical pumpkins provide a valuable source of carotenoids that have a major role in nutrition as provitamin $\mathrm{A}$ and antioxidants. Total carotenoids were determined on pumpkin fruit grown in Bradenton, Fla., in the Spring 2001 season (Table 3) according to the methods of Gross (1991) and Talcott and Howard (1999). These data are consistent with the field ratings of color in 'El Dorado' and 'La Estrella' fruit. The new hybrids are significantly higher in Hunter a and Hunter hue than 'La Primera', indicating a brighter orange flesh color. Total carotenoid production per unit of land area is much higher in 'El Dorado' than in 'La Estrella' or 'La Primera' because of higher yields.

Carotenoid concentrations in tropical pumpkin compare favorably with those sum- 

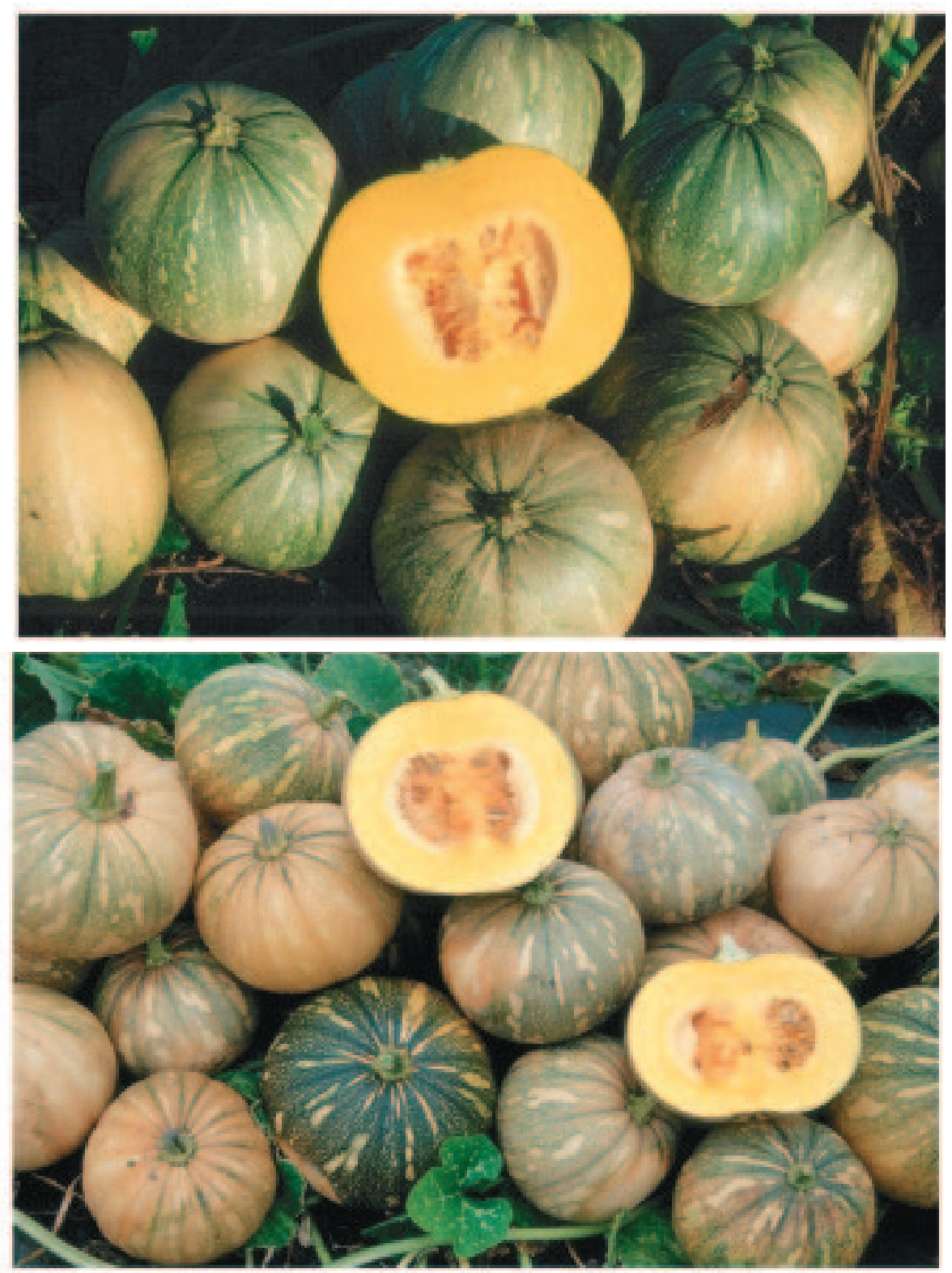

Fig. 2. (top) 'El Dorado' and (bottom) 'La Estrella' tropical pumpkin fruit.

Table 3. Total carotenoid and Hunter color values for tropical pumpkin cultivars. Spring 2001.

\begin{tabular}{lcccccr}
\hline Cultivar & $\begin{array}{c}\text { Carotenoids } \\
\left(\mathrm{mg} \cdot \mathrm{kg}^{-1} \mathrm{FM}\right)\end{array}$ & $\begin{array}{c}\text { Hunter } \\
\mathrm{L}^{* 2}\end{array}$ & $\begin{array}{c}\text { Hunter } \\
\mathrm{a}^{* y}\end{array}$ & $\begin{array}{c}\text { Hunter } \\
\mathrm{b}^{\mathrm{x}}\end{array}$ & $\begin{array}{c}\text { Hunter } \\
\text { Hue }\end{array}$ & $\begin{array}{c}\text { Hunter } \\
\text { chroma }^{\text {v }}\end{array}$ \\
\hline El Dorado & $56.82 \mathrm{a}^{\mathrm{u}}$ & $73.24 \mathrm{a}$ & $17.70 \mathrm{a}$ & $39.28 \mathrm{a}$ & $65.82 \mathrm{~b}$ & $43.11 \mathrm{a}$ \\
La Estrella & $48.92 \mathrm{~b}$ & $69.28 \mathrm{~b}$ & $16.88 \mathrm{a}$ & $38.08 \mathrm{a}$ & $66.14 \mathrm{~b}$ & $41.72 \mathrm{a}$ \\
La Primera & $51.67 \mathrm{ab}$ & $71.13 \mathrm{ab}$ & $14.27 \mathrm{~b}$ & $40.08 \mathrm{a}$ & $70.42 \mathrm{a}$ & $42.67 \mathrm{a}$ \\
\hline
\end{tabular}

${ }^{2} L^{*}=$ lightness values $(100=$ white; $0=$ black $)$.

${ }^{y} a^{*}=$ redness, the higher the value the more red the flesh.

${ }^{x} b^{*}=$ yellowness, the higher the value the more yellow the flesh.

${ }^{\mathrm{w}} \mathrm{Hue}$ angle $=$ measured in degrees from $0^{\circ}$ to $360^{\circ}$. For this product, $0^{\circ}=$ red, $45^{\circ}=$ orange, and $90^{\circ}=$ yellow .

"Chroma $=$ measures color intensity, the higher the value, the "brighter" the flesh appearance.

"Mean separation in columns by Duncan's multiple range test, $5 \%$ level. marized by Paris (1994) for butternut squash (C. moschata). Concentrations from four studies varied from 15.0 to $85.0 \mathrm{mg} \cdot \mathrm{kg}^{-1} \mathrm{FM}$ with an average of $45.5 \mathrm{mg} \cdot \mathrm{kg}^{-1} \mathrm{FM}$, which is less than that obtained for tropical pumpkin.

\section{Availability}

'El Dorado' and 'La Estrella' hybrid tropical pumpkin seeds are available for research purposes from the senior author. Florida Foundation Seed Producers, P.O. Box 309, Greenwood, FL 32443, has licensed Rupp Seeds, Inc., 17919 Co. Rd. B., Wauseon, OH 43567, to produce and market seeds of 'El Dorado' and 'La Estrella'.

\section{Literature Cited}

Alamo, C.I. 1990. Hortalizas, p. 4-13. In: M. Antoni, M. Cortes, G.M. Gonzales, and S. Velez (eds.). Situación y perspectivas: Empresas agrícolas de Puerto Rico en 1987-88. Estación Experimental Agrícola, Univ. of Puerto Rico, Mayaguez.

Gross, J. 1991. Carotenoids. Pigments in vegetables: Chlorophylls and carotenoids. Van Nostrand Reinhold, New York.

Munger, H.M. 1990. Availability and use of interspecific populations involving Cucurbita moschata and C. pepo. Cucurbit Genet. Coop. Rpt. 13:49.

Paris, H.S. 1994. Genetic analysis and breeding of pumpkins and squash for high carotene content. Modern methods of plant analysis. Vegetables and vegetable products. 16:93-115. SpringerVerlag, Berlin.

Talcott, S.T. and L.R. Howard. 1999. Phenolic autoxidation is responsible for color degradation in processed carrot purée. J. Agr. Food Chem. 47:2109-2115.

Volin, R.B. 1979. La Primera. A calabaza for Florida and the tropics. Florida Agr. Expt. Sta. Circ. S261.

Volin, R.B., W.M. Stall, and R.F. Mathews. 1976. Selection and evaluation of improved plant lines in calabaza, Cucurbita moschata. Proc. Trop. Reg. Amer. Soc. Hort. Sci. 24:402-409. 